\title{
EDITORIAL
}

DOI: $10.53116 /$ pgaflr.2021.2.1

\section{Privacy and Governmental Transparency}

\author{
* University of Public Service, e-mail: koltay.andras@uni-nke.hu \\ ** Centre for Social Sciences, e-mail: konczol.miklos@tk.hu \\ *** University of Győr, e-mail: lapsanszky.andras@sze.hu \\ ****University of Public Service, e-mail: tussay.akos@uni-nke.hu
}

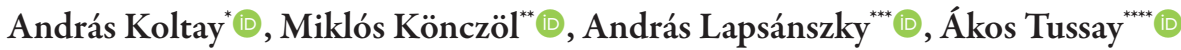

The second, semi-thematic issue of our 2021 volume comprises the proceedings of a conference as well as research papers. On 7-8 June 2021, Pázmány Péter Catholic University's Faculty of Law (Budapest, Hungary), the University of Stockholm's Faculty of Law (Stockholm, Sweden), the University of Windsor's Faculty of Law (Windsor, Canada), the University of Alabama's School of Law (Tuscaloosa, USA), Université Paris Dauphine-PSL Research University (Paris, France), Emory University's School of Law (Atlanta, USA), and the University of Louisville's Louis D. Brandeis School of Law co-hosted an online Forum on Privacy and Governmental Transparency. The goal of this forum was to bring together a small group of prominent scholars to facilitate a multidisciplinary discussion on privacy and transparency. Today, in times of the Covid-19 pandemic, with governments introducing special legislation and track-andtrace measures to combat the virus (see Hoffman \& Balázs, 2021; Karácsony \& Nagypál, 2021), and the societal impact of social media reaching new peaks (Cinelli et al., 2020), the significance of privacy and governmental transparency would be hard to deny. With that significance in mind, the first four articles are based on papers presented at the Forum, while the following articles address various themes within the conceptual domains of public administration and jurisprudence.

The first article, Robert Kahn's Masks, Face Veil Bans and "Living Together". What's Privacy Got to Do with It? considers the concept of "living together" and its implications to privacy, with a special focus on the requirement of modern democracies to show one's face in public. Next, Algorithms of Machines and Law: Risks in Pattern Recognition, Machine Learning and Artificial Intelligence for Justice and Fairness, by Michael Losavio, elaborates on the opportunities and the inherent risks in adopting AI technologies, such as facial recognition in the public sphere, predominantly in law enforcement. The third piece of the proceedings, Public Registries as Tools for Realising the Swedish Welfare State - Can the State Still be Trusted?, authored by Jane Reichel and Johanna Chamberlain, argues that the high level of social trust in the Swedish society is mostly due to citizens' general trust in one another as well as in public institutions, which is 
further enhanced by the transparent operation of the latter, and the credibility of their official records. However, a number of Swedish "register scandals" may threaten these achievements: it is for that reason that they urge a careful balance between transparency and the right to privacy. Finally, the fourth article, Russell Weaver's The Constitutional Implications of Drones, Facial Recognition Technology and CCTV, examines how courts in the USA assess and implement new surveillance technologies, such as drones and CCTV.

The fifth article, by Zoltán Hazafi and Enikő Kovácsné Szekér, addresses a Hungarian issue, that of the Introduction of the Personal Decision Support IT System in the Hungarian Public Service. The sixth, Ágnes Orosz and Norbert Szijártós Socioeconomic Governance in the EU gives an overview of the EU framework of social and economic governance. The seventh piece, by Boldizsár Szentgáli-Tóth, The Source of Unexplored Opportunities or an Unpredictable Risk Factor? Could Artificial Intelligences Be Subject to the Same Laws as Human Beings? inquires into the problematic relationship between the adoption of AI technologies and the idea of the rule of law, especially with a view to its challenges to law and policy-making. The last article, Ádám Varga's Local Self-Governments and the Vertical Division of Power, considers, once again, a Hungarian issue: it deals with the role Hungarian local self-governments play within the Hungarian constitutional system.

\section{References}

Cinelli, M., Quattrociocchi, W., Galeazzi, A. et al. (2020). The COVID-19 social media infodemic. Scientific Reports, 10(16598). Online: https://doi.org/10.1038/s41598-020-73510-5

Hoffman, I., \& Balázs, I. (2021). Administrative Law in the Time of Corona(virus): Resilience and Trustbuilding. Public Governance, Administration and Finances Law Review, 6(1), 35-50. Online: https:// doi.org/10.53116/pgaflr.2021.1.4

Karácsony, A., \& Nagypál, Sz. (2021). The Rule of Law and the Extraordinary Situation. Public Governance, Administration and Finances Law Review, 6(1), 65-72. Online: https://doi.org/10.53116/pgaflr.2021.1.6 